\title{
Genetic Study of Resistance to Begomovirus on Chili Pepper by Hayman's Diallel Analysis
}

\author{
Dwi Wahyuni Ganefianti", Sri Hendrastuti Hidayat", Muhamad Syukur ${ }^{1}$ \\ \# Department of Agriculture Production, Faculty of Agriculture, University of Bengkulu, Bengkulu 38371A, Indonesia \\ E-mail: ganefianti_crp@yahoo.com \\ * Department of Agronomy and Horticulture, Faculty of Agriculture, Bogor Agricultural University, Bogor, Indonesia \\ ${ }^{1}$ Department of Plant Protection, Faculty of Agriculture, Bogor Agricultural University, Bogor 166080, Indonesia
}

\begin{abstract}
Genetic study of resistance to Begomovirus is required in plant breeding program to obtain a resistance cultivar. Diallel analysis was used to evaluate the genetic parameters in early generation for Begomovirus resistance and agronomic characters. Fourty two hybrids and 7 selfed families generated from a full diallel cross of seven parental lines varying in Begomovirus resistance and yield potential were allotted in a randomized complete block design with three replications. Virus infection was made by inoculating 'Segunung' isolate from infected plant using Bemisia tabaci as the vector. Results showed that disease intensity, types of symptoms and fruit number were controlled by genes interaction. Fruit weight was controlled by additive gene actions, whereas incubation period were controlled by dominant gene actions. Disease intensity, types of symptoms and incubation period showed over-dominant gene actions towards lower intensity and longer incubation period respectively. The broad sense and narrow sense heritability for all characteristics are classified as moderate to high.
\end{abstract}

Keywords - genetic parameters; Begomovirus; Bemisia tabaci; diallel analysis

\section{INTRODUCTION}

Yellow curl leaf disease is serious disease of chili pepper in Indonesia and other countries in the world. This disease is caused by Begomovirus (Family: Geminiviridae) known as Pepper yellow leaf curl Begomovirus (PYLCV). Survey of this disease in the field in chili pepper producing regions in Indonesia showed that disease intensity has increased fast. The infection of this virus on chili pepper was reported for the first time by [1]. This disease spread quickly and inflicted great loss to farmers in correlation with the population increase of Whitefly (Bemisia tabaci) as a vector which spread this virus persistently. Begomovirus infection can caused chili pepper become stunted [2], and fail to fruit or the fruits are deformed.

Controls of this disease have been done by farmers using various methods, i.e improvement of cultivation techniques, Erradication of infected plants, construction of plant border to prevent vector dispersal and use of pesticides to control the vector. The methods to control this disease have not been effective because they did not kill the whole population of whitefly. Whereas even only one whitefly can infect the plants with the virus. Therefore, the use of whitefly-resistant plant variety is the most appropiate method to control this disease. Resistant varieties are created by breeders through a set of plant breeding programs. Behavior of genes which control resistance can be studied using genetic parameters estimation.

Diallel analysis is a frequent used method to estimate genetic parameter. Experimentally, this analysis is a systematic approach. Analytically, this analysis is a comperehensive genetic evaluation useful to identify hybridization at early generation selection [3]. Diallel hybridization is developed to get information of genetic mechanisms involved at early generation [4]. Diallel analysis can estimate additive or dominant gene action of population, which in turn can estimate genetic variability and heritability [5]. According to [6], diallel hybridization enables us to select parent.

So far, the researches on genes which control Begomovirus are limited, and have not been done on chili pepper. It has been reported that tomato's resistance to Begomovirus is controlled by several genes [7]. Morales also reported that virus-resistant genes in peas are additive. However, reference stated that pea's resistance to Bean dwarf mosaic geminivirus was controlled by a single dominant gene. Reference [8] also reported that peas' 
resistance to Begomovirus is controlled by a single dominant gene. Breedings to create tomatoes and peas varieties resistant to Begomovirus have been done intensively, and varieties resistant to Begomovirus have been created. However, there have been no chili pepper varieties resistant to Begomovirus reported. This research provides information on genetic heredity that control Begomovirus resistance.

\section{MATERIALS AND METHODS}

This reseach was conducted in screen house, green house and education laboratory of Bogor Agriculture University. Genotypes which were selected to form dialell crossing were IPBC10, IPBC12, IPBC14, IPBC15, IPBC18, IPBC26 dan $35 \mathrm{C} 2$. The selected genotypes were those which had high resistance to Begomovirus, superior agronomic characters and high yield. Full diallel crossing was conducted to get 49 crossing combinations. F1 seeds were harvested and used for the experiment. The seeds were germinated at plastic trays with 72 holes. The seedlings were 14 days old, they were moved into $35 \times 40 \mathrm{~cm}$ - polybags filled with $6 \mathrm{~kg}$ of soil and $0,5 \mathrm{~kg}$ of manure. Fertilitation and plant care were done in accordance with chili pepper cultivation guide/manual.

16-day-old plants were innoculated using vector incect Bemisia tabaci which have been acquiredwith Begomovirus 'Segunung' isolate. The aquitition was conducted for 24 hours. Furthermore, plants were innoculated using individual innoculated methods [2] and they were left undisturbed for 48 hours to get innoculation period. All plants were placed in block, each block having 10 plants. The research was arranged using Completetly Rondomized Blocked Design, with 3 blocks. The treatment was chili pepper genotypes which consisted of 49 genotypes, F1 full diallel from 7-parent. The hybridization was done at wire house in Bengkulu. The F1 trials were done at green house in Bogor Agriculture University, using $35 \mathrm{~cm} \mathrm{x} 40 \mathrm{~cm}$ polibags, following the standard cultivation procedures of chili pepper [1].

The characters observed were incubation period, symptom types, disease intensity, number and weight of fruits. The disease symptoms were observed during the first harvest period. The intensity of symptoms was scored from 0 to 5 [2]. The intensity of disease was used to determined severity level of Begomovirus infection in genotype which was tested with formula [9]. IP $=[\Sigma($ ni $\times \mathrm{zi}) /(\mathrm{N} \times \mathrm{Z}) \times 100 \%$, with $\mathrm{i}=0-5$ score, $\mathrm{ni}=$ sum of plant symptoms with score value, $\mathrm{zi}=$ value of symptoms score, $\mathrm{N}=$ sum of plant, and $\mathrm{Z}$ $=$ hight score of symptoms.

The data were analyzed using analysis variance, followed by an analysis dialel Hayman approach and correlation analysis on SAS 9.

\section{RESULTS AND DISCUSSION}

\section{A. Evaluation of Parent and F1}

The intensity of plant diseases of parent and F1 was presented in Table I. The parent plants resisted to Begomovirus infection were IPBC12 and IPBC26. IPBC10 and IPBC14 were moderately resistant. IPBC18 was moderately vulnerable, while IPBC 15 and $35 \mathrm{C} 2$ were highly vulnerable parent plants. Some of these resistant levels of parent were the same as the results of the evaluation by [2] that were IPBC12 as resistant parent, IPBC10 as moderately resistant parent, IPBC18 as somewhat vulnerable parent, and $35 \mathrm{C}$ as very susceptible genotypes parent. While IPBC14 and IPBC15 parent were changed their resistance categories. IPBC14 parent formerly was vulnerable category become resistant and IPBC15 was changed from somewhat prone to be vulnerable.

Cross between resistant and very susceptible parent (IPBC12 x 35C) yielded resistant F1 plants, but their reciprocal cross produced susceptible plants. Cross between resistant and extremely vulnerable parent (IPBC26 x 35C) resulted in a moderately vulnerable $\mathrm{F} 1$, but their reciprocal cross produced plants that are highly vulnerable. Cross between somewhat resistant and highly susceptible parent (IPBC10 x 35C) resulted in F1 plants that were moderately resistant, but their reciprocal cross generated moderately vulnerable plants. These results indicate that there are differences in the intensity of the pepper plant disease caused by infection Begomovirus between direct and reciprocal F1. If the female parent is a plant resistant or moderately resistance and highly susceptible males, then F1 plant has a higher resistance than if the cross is done between a very vulnerable female parent and resistant male parent.

TABLE I

DisEASE INTENSITY AND RESILIENCE CATEGORIES OF PARENT AND F1 CHILI PEPPER INFECTED BY BEGOMOVIRUS

\begin{tabular}{|c|r|r|r|r|r|r|}
\hline & IPBC10 & IPBC12 & IPBC14 & IPBC15 & IPBC18 & IPBC26 \\
\hline & 8.000 & 2.000 & 6.000 & 9.000 & 14.000 & 27.000 \\
IPBC10 & $\mathrm{AT}$ & $\mathrm{T}$ & $\mathrm{AT}$ & $\mathrm{AT}$ & $\mathrm{AR}$ & $\mathrm{R}$ \\
\hline & 0.000 & 1.000 & 0.000 & 0.000 & 3.000 & 0.000 \\
IPBC12 & $\mathrm{I}$ & $\mathrm{T}$ & $\mathrm{I}$ & $\mathrm{I}$ & $\mathrm{T}$ & $\mathrm{I}$ \\
\hline & 8.000 & 1.000 & 6.000 & 10.000 & 8.000 & 30.000 \\
IPBC14 & $\mathrm{AT}$ & $\mathrm{T}$ & $\mathrm{AT}$ & $\mathrm{AT}$ & $\mathrm{AT}$ & $\mathrm{R}$ \\
\hline & 12.000 & 21.000 & 15.000 & 24.000 & 41.000 & 22.000 \\
IPBC15 & $\mathrm{AR}$ & $\mathrm{R}$ & $\mathrm{AR}$ & $\mathrm{R}$ & $\mathrm{R}$ & $\mathrm{R}$ \\
\hline & 21.000 & 18.000 & 27.000 & 30.000 & 12.000 & 0.000 \\
IPBC18 & $\mathrm{R}$ & $\mathrm{AR}$ & $\mathrm{R}$ & $\mathrm{R}$ & $\mathrm{AR}$ & $\mathrm{I}$ \\
\hline & 6.000 & 0.000 & 3.000 & 22.000 & 0.000 & 2.000 \\
IPBC26 & $\mathrm{AT}$ & $\mathrm{I}$ & $\mathrm{T}$ & $\mathrm{R}$ & $\mathrm{I}$ & $\mathrm{T}$ \\
\hline & 19.143 & 29.000 & 32.000 & 33.000 & 41.000 & 57.000 \\
$35 \mathrm{C}$ & $\mathrm{AR}$ & $\mathrm{R}$ & $\mathrm{R}$ & $\mathrm{R}$ & $\mathrm{SR}$ & $\mathrm{SR}$ \\
\hline
\end{tabular}

Cross between susceptible and very susceptible parent (IPBC15 x 35C) produced vulnerable F1 plant, but their reciprocal cross generated very vulnerable plant. While crosses between moderately susceptible and very susceptible (IPBC18 x 35C) produced vulnerable F1 plant, but their reciprocal cross generated very susceptible plants. The combination of these crosses also showed that cross between the female parent plants that had a higher resistance than the male parent plant would produce the F1 generation which resistance was higher than the F1 plants generated from their reciprocal cross. Based on these findings, there are differences in plant resistance of F1 chili pepper plants than their reciprocal F1 chili pepper plants. If a character is influenced by female parent then reciprocal cross offspring will give different results, and the offspring shows the characteristics of the female parent [10]. There has been no report on the effect of the extrachromosomal inheritance of pepper plants to Begomovirus, the inheritance of resistance 
of tomato plants to Begomovirus generally controlled by genes that exist in the core. The influence of maternal in reaction of cassava resistance to Colletotricum gliesporioides f sp manihotis was studied. Another study [11] suggested that the whole nature of corn that tested only one ear height properties that indicate maternal inheritance. Reference suggests that there is a reciprocal effect on the inheritance of grain quality of sweet corn, indicating there is an interaction between the nucleus and cytoplasm gene.

\section{B. Genetic Parameter Estimation}

Genetic parameters can be estimated using analysis of dialel analysis if the analysis of variance of genotype showed significantly different. Results of analysis of variance that were performed on all variables showed significantly different for all variable (Table 2).

TABLE II

GENOTYPE OF RESISTANCE AND AGRONOMIC VARIABLES ON BEGOMOVIRUS INFECTED PLANTS

\begin{tabular}{|l|l|}
\hline \multicolumn{1}{|c|}{ Source of Variance } & \multicolumn{1}{c|}{ Genotype } \\
\hline Disease intensity (\%) & $584.129 * *$ \\
Score/typeof symptoms & $3.74 * *$ \\
Incubation period (days) & $353.36^{* *}$ \\
Number of fruit & $1438.370^{* *}$ \\
Weight of fruit (g plant $\left.{ }^{-1}\right)$ & $14357.370^{* *}$ \\
\hline
\end{tabular}

\section{Gene Interaction}

Results of t-test to test the b coefficient of regression ( $\mathrm{Wr}$, $\mathrm{Vr}$ ) for the variable intensity of the disease, score/type of symptoms and the number of fruits showed significantly different, however the incubation period and the weight of fruit per plant showed no significantly different (Table III). Thus, the variables of intensity of the disease, score/type of symptoms and the amount of fruit showed an interaction between non-allelic genes. On the other hand, the variables of incubation period and the weight of fruit per plant did not show non-allelic interaction. Research conducted on chili pepper resistance to Phytophthora capsici showed gene interactions. Research conducted shows the value of regression coefficient $b$ is not significantly different to one and there was no action of epistatic genes that play a role in the appearance of fruit weight per plant. The $b$ coefficient regression ( $\mathrm{Wr}$ and $\mathrm{Vr}$ ) which were not significantly different leaded to one of the assumptions of the analysis of cross dialel can be met, otherwise the significantly different caused one of the assumptions could not be met.

\section{Influence of Additive and Dominance}

Each of the observed variables indicated significantly effect of the additive and dominance. The influence of additives (D) and dominant (H1) acts together significantly in inheritance of disease intensity character $(\mathrm{D}=183.94 * *$, $\mathrm{H} 1=192.82 * *), \quad$ score/type symptoms $\quad(\mathrm{D}=1.26 * *)$ $\left.\mathrm{H} 1=1.55^{* *}\right)$ and the incubation period $\left(\mathrm{D}=92.35^{* *}\right.$, $\mathrm{H} 1=279.64$ (Table III). In the inheritance of disease intensity character, score/type of symptoms and the incubation period, the influence of the dominant was greater than the influence of additives $(\mathrm{D}<\mathrm{H} 1)$. Reference showed that chili pepper disease resistance to Phytophthora capsici was influenced greater by a dominant gene than additive. In the inheritance of the number of fruit $\left(\mathrm{D}=194.25^{* *}, \mathrm{H} 1=-117.60^{\mathrm{ns}}\right)$ and weight of fruit per plant $\left(\mathrm{D}=3626.50^{* *}, \mathrm{H} 1=-722.45^{\mathrm{ns}}\right)$, additive factors play a bigger role than dominant. The effect of additive gene that is greater than from a dominant gene in these characters provide an explanation that the characters can be passed on to their offspring. According to [12], the effect of additive gene which is greater indicate that the observed characters influenced by additive gene. Research conducted by [13] the additive effect (D) on the weight of fruit per plant chili was greater than the dominant influence (H1).

\section{E. Gene Distribution in the Parent}

The distribution of genes in the parent can be seen from the value of $\mathrm{H} 2$. Genes that determine the intensity of disease inheritance character $\left(\mathrm{H} 2=168.76^{* *}\right)$, score/type symptoms $\left(\mathrm{H} 2=1: 41^{*}\right)$, and the incubation period $(\mathrm{D}=218.64 * *)$, showed highly significant and significant. This means that the distribution of genes not spread evenly in the parent. In contrast, the characters of number of fruit $\left(\mathrm{H} 2=-66.19^{\mathrm{ns}}\right)$ and fruit weight $\left(-326.36^{\mathrm{ns}}\right)$ were not significantly different. This means that the genes that determine the inheritance of the these characters spread evenly in the parent (Table 3).

The proportion of positive genes to negative genes can be observed from the value of $\mathrm{H} 1$ to $\mathrm{H} 2$. If $\mathrm{H} 1$ is greater than $\mathrm{H} 2$, the genes which dominated genes are positive, otherwise if $\mathrm{H} 1$ is smaller than $\mathrm{H} 2$, the negative genes is more dominated than positive genes. The proportion of positive to negative genes is also reflected on the value of $\mathrm{H} 2 / 4 \mathrm{H} 1$. Characters of the disease intensity, score/type of symptoms and the incubation period have a value greater than $\mathrm{H} 2 / 4 \mathrm{H} 1$ indicating that positive genes more dominance than negative genes. The $\mathrm{H} 1$ value of characters of fruit number and fruit weight is smaller than $\mathrm{H} 2$. This indicates that negative genes more dominance than positive genes. Research found that the value of $\mathrm{H} 1$ is greater than $\mathrm{H} 2$ on the resistance chili pepper to Phytophthora capsici.I Reference [13] suggests that the weight of fruit per plant in chili pepper has genes involved more positive than negative genes since the value of $\mathrm{H} 1$ is greater than $\mathrm{H} 2$.

\section{F. Dominance Level, Direction and Sequence of Dominance}

The level of dominance is implied by the value of $(\mathrm{H} 1 / \mathrm{D})^{1 / 2}$. If the value of (H1/D) $)^{1 / 2}$ between zero and one. It shows partial dominance (partially recessive or partially dominance). If the values of $(\mathrm{H} 1 / \mathrm{D})^{1 / 2}$ more than one, it indicates over-dominant [13]. The dominance level value which is greater than one shown by characters of the intensity of the disease (1.02), score/type symptoms (1.11) and the incubation period (1.74), so all three of these characters indicates over-dominant. Characters of number of fruit $(0.00)$ and fruit weight $(0.00)$ indicates a value less than one (Table 3), this indicates a partial dominance.

If the value of $\mathrm{r}(\mathrm{Wr}+\mathrm{Vr}<\mathrm{Yr})$ is positive, the quantification value of the low characters is dominance to the high characters. If the value of $\mathrm{r}(\mathrm{Wr}+\mathrm{Vr}<\mathrm{Yr})$ is negative, then the quantification value of the high characters is dominance to the low characters. Dominant traits possessed by a low intensity disease, high score/type of 
symptoms, fast incubation period, the little number of fruit, but high fruit weight per plant.

The sequence of dominance of parent for the desease intensity character is IPBC10 (81.42), IPBC12 (88.08), IPBC14 (110.69), 35C2 (141.81), IPBC15 (149.49), IPBC18 (173.02) and IPBC26 (191.64), as shown in Figure 1. The closer the location of the point on the regression line is the more dominant of the parent, IPBC12 and IPBC10 are located closest to the origin point, so it is the most dominant parent. While IPBC18 and IPBC26 are parent with a little dominant gene, so their position lies far from the origin point.

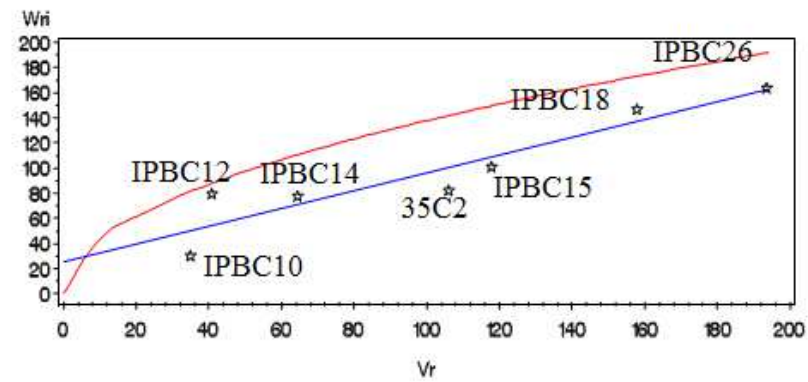

Fig. 1 Relationship between covariance $(\mathrm{Wr})$ and variance $(\mathrm{Vr})$ for disease intensity character

The sequence of dominance of parent for score/type of symptom is IPBC15, 35C2, IPBC12, IPBC10, IPBC14, IPBC18 and IPBC26, as shown in Figure 2. The closer the location of the point on the regression line is the more dominant of the parent. So the most dominant parent of high score/type of symptom is IPBC15 and 35C. IPBC18 and IPBC26 parent are most recessive (contains few dominant genes).

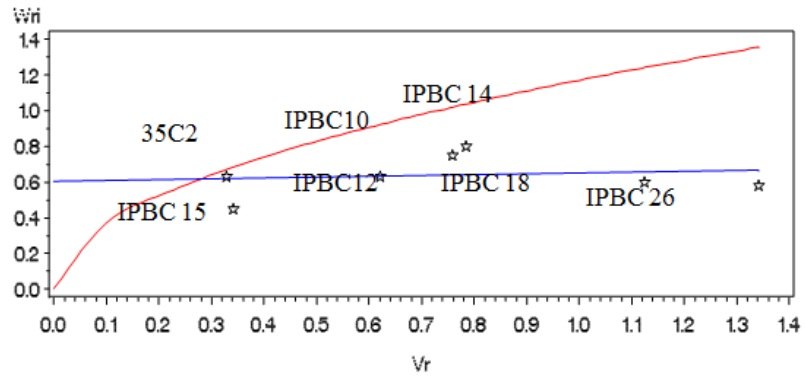

Fig. 2 Relationship between covariance (Wr) and variance (Vr) for score/type of symptom character

The sequence of dominance of parent for the incubation period character (incubation period of rapid and susceptible plants) is IPBC15 (42 008), IPBC14 (45.77), IPBC10 (51.61), IPBC26 (86.17), 35C (90.16), and IPBC12 (112.46), as shown in Figure 3. The closer the location of the point on the regression line is the more dominant the parent. So the most dominant parent for rapid incubation period is IPBC15, while IPBC12 is a parent with a slightly dominant gene.

The sequence of dominance of parent for the number of fruit character is IPBC18 (152.68), IPBC15 (160.71), IPBC26 (188.54), 35C (256.86), IPBC12 (271.30), IPBC14 (338.20) and IPBC10 (348.81), as shown in Figure 4. The IPBC18 and IPBC15 parents are adjacent and situated close to the axis of origin, so that the two parents are parent of the most dominant and IPBC10 is the most recessive parent.

The sequence of dominance of parent for fruit weight character is IPBC15 (1816.34), IPBC26 (2094.80), IPBC10
(2525.55), IPBC12 (2674.550), IPBC14 (2897.85), 35C (3625.29) and IPBC18 (3863.47), as shown in Figure 5. The IPBC15 parent is adjacent and situated close to the axis of origin, so that this parent is a parent of the most dominant and IPBC18 is the most recessive parent. According to the most dominant chili pepper parent that resistant to Phytophthora capsici is IPBC-4, because it is located closest to the origin point. In a study conducted by [12], IPBC120 parent have the highest sequence of dominance for the weight of fruit per plant, IPBC2 for length of fruit and IPBC159 for diameter of the fruit. This character is closest to zero indicating the content of the most dominant genes.

The number of groups of genes that control the characters and caused domination is indicated by the value of $\mathrm{h} 2 / \mathrm{H} 2$. All the characters show values smaller than one, thus the numbers of groups of genes that control the five variables were observed as one group of genes.

TABLE III

Estimated Genetic PARAMETERS ON CROSS DiaLLEL ON BEGOMOVIRUS INFECTED PLANTS

\begin{tabular}{|c|c|c|c|c|c|}
\hline & IP & SKR & MI & $\mathrm{JBH}$ & $\mathrm{BBBH}$ \\
\hline $\mathrm{b}(\mathrm{Wr}, \mathrm{Vr})$ & $0.70^{* *}$ & $0.04^{* *}$ & $0.37^{\mathrm{ns}}$ & $0.48 * *$ & $0.76^{\mathrm{ns}}$ \\
\hline $\mathrm{D}$ & $183.94 * *$ & $1.26^{* * *}$ & $92.35^{*}$ & $194.25^{* *}$ & $3626.5^{* *} *$ \\
\hline $\mathrm{H} 1$ & $192.82 * *$ & $1.55^{* *}$ & $279.64 * *$ & $-117.60^{\mathrm{ns}}$ & $-722.45^{\mathrm{ns}}$ \\
\hline $\mathrm{H} 2$ & $168.76^{* *}$ & $1.41 *$ & $218.64 * *$ & $-66.16^{\mathrm{ns}}$ & $-326.36^{\mathrm{ns}}$ \\
\hline $\mathrm{F}$ & $20.04^{\mathrm{ns}}$ & $0.03^{\mathrm{ns}}$ & $102.34^{\mathrm{na}}$ & $-360.4^{* *}$ & -1574.62 \\
\hline$h^{2}$ & $22.66^{\mathrm{ns}}$ & $0.06^{\mathrm{ns}}$ & $79.27^{\mathrm{ns}}$ & $8.38^{\text {ns }}$ & $174.62^{\mathrm{ns}}$ \\
\hline $\mathrm{E}$ & $5.53 * *$ & $0.10^{\text {ns }}$ & $5.30^{\mathrm{ns}}$ & $146.49 * *$ & $1070.42 * *$ \\
\hline$(\mathrm{H} 1 / \mathrm{D})^{1 / 2}$ & 1.02 & 1.11 & 1.74 & 0.00 & 0.00 \\
\hline $\mathrm{H} 2 / 4 \mathrm{H} 1$ & 0.21 & 0.22 & 0.19 & . & . \\
\hline $\mathrm{Kd} / \mathrm{Kr}$ & 1.00 & 1.02 & 1.93 & . & . \\
\hline $\mathrm{h}^{2} / \mathrm{H} 2$ & 0.13 & 0.04 & 0.36 & . & . \\
\hline $\mathrm{R}$ & 0.01 & -0.32 & 0.61 & 0.79 & -0.23 \\
\hline $\mathrm{h}^{2} \mathrm{bs}$ & 96.00 & 90.80 & 93.00 & 39.87 & 62.88 \\
\hline$h^{2} n s$ & 68.00 & 60.00 & 29.00 & 39.87 & 62.88 \\
\hline YD & 129.94 & 2.11 & 22.41 & 135.96 & 2495.83 \\
\hline $\mathrm{Yr}$ & -124.08 & 2.01 & 3.25 & -160.81 & -2409.09 \\
\hline
\end{tabular}

Notes: IP=disease intensity $(\%) . \quad \mathrm{SKR}=$ score/type of symptoms. $\mathrm{MI}=$ inkubation period (his) $\mathrm{JBH}=$ number of fruit. $\mathrm{BBBH}=$ weight of fruit $\left(\mathrm{g}\right.$ plant $\left.{ }^{-1}\right)$

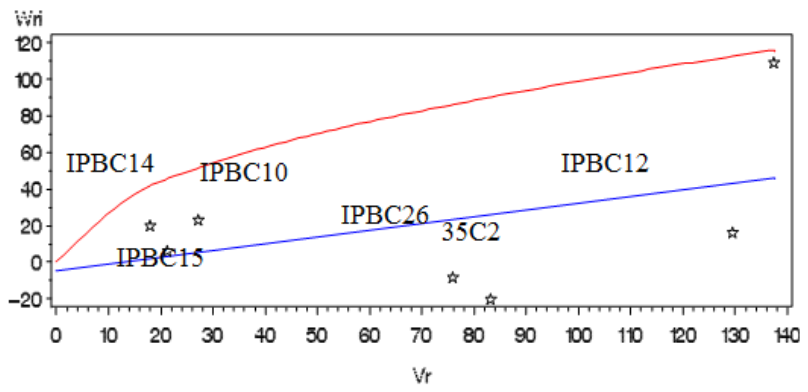

Fig. 3 Relationship between covariance (Wr) and variance (Vr) for incubation period character 


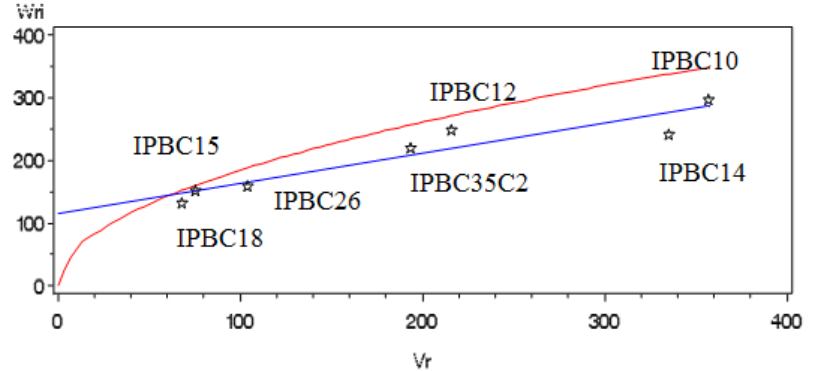

Fig. 4 Relationship between covariance (Wr) and variance (Vr) for number of fruit character

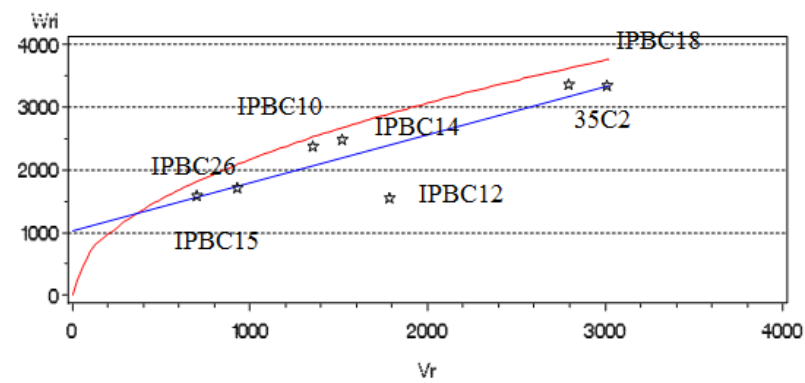

Fig. 5 Relationship between covariance (Wr) and variance (Vr) for weight of fruit character

\section{G. Heritability}

Estimation of heritability values in broad sense on four variables is high, the intensity of the disease (96.00\%), score/type of symptoms $(90.81 \%)$, the incubation period $(93.00 \%)$, and weight of fruit per plant $(62.88 \%)$, while the numbers of fruits $(39.87 \%)$ have moderate value. This indicates that the four variables are controlled by genetic factors. Previous research showed that the high heritability values on the weight of fruit per plant [13]; [15], resistance to Phytophthora capsici disease. Furthermore, the study of antraknose disease resistance showed heritability in broad and narrow sense in the medium category. In addition, the estimation of heritability value in narrow sense that high found in the character of the disease intensity (68.00\%), score/type of symptoms $(60.00 \%)$ and fruit weight $(62.88 \%)$, while the number of fruits $(39.87 \%)$ had moderate values. These findings indicate that the proportion of additive variance observed on each character is high.

\section{H. Relationship between Characters}

The relationship between the intensity of plant diseases infected by Begomovirus on chili pepper with all the characters that were observed in this study is expressed by the correlation coefficient (Table IV). There is a positive correlation and highly significant between the intensity of the disease and score/type of symptoms $(0.69 * *)$. On the other hand, there is a negative correlation and significant between the real and the intensity of the disease and the number of fruit $\left(-0.16^{*}\right)$. There is no significant correlation between the intensity of the disease and an incubation period $\left(-0.05^{\mathrm{tn}}\right)$ and fruit weight $\left(-0.07^{\mathrm{tn}}\right)$. The number of fruit correlate significantly with fruit weight $(0.79 * *)$.

Phenotype is a combination of genetic diversity and environmental influences. Genetic diversity is the diversity caused by the effect of the additive, dominance and interaction between genes [14]. Results estimate genetic parameters on the characters of chili pepper infected
Begomovirus indicate that the interaction between genes occur in the intensity of disease inheritance character, score/type of symptoms and the amount of fruit. These results indicate that one of the assumptions are not met dialel analysis. According to [16] for the type of complementary interaction will shift the regression line $(\mathrm{Wr}, \mathrm{Vr})$, increase the value $(\mathrm{H} 1 / \mathrm{D})^{1 / 2}$, depress the value of $\mathrm{h} 2 / \mathrm{H} 2$, but have little effect on the estimates of gene frequencies $(\mathrm{H} 2 / 4 \mathrm{H} 1)$; whereas the type of interaction will suppress duplicate values $\mathrm{h} 2 / \mathrm{H} 2$, increasing the proportion of dominant genes $(\mathrm{Kd} / \mathrm{Kr})$, but less influence $(\mathrm{H} 1 / \mathrm{D})^{1 / 2},(\mathrm{H} 2 / 4 \mathrm{H} 1)$, and the regression line $(\mathrm{Wr}, \mathrm{Vr})$. Leaving aside the type of interaction that exists, then the value of the parameter estimation $(\mathrm{H} 1 / \mathrm{D})^{1 / 2}, \mathrm{~h} 2 / \mathrm{H} 2$, (H2/4H1), and $\mathrm{Kd} / \mathrm{Kr}$ for characters that are affected by interactions between genes cannot be fully used.

\section{TABLE IV}

THE CORRELATION BETWEEN THE DISEASE INTENSITY AND DISEASE/AGRONOMIC CHARACTERS

\begin{tabular}{|l|l|}
\hline Character & $\mathrm{R}$ \\
\hline Score/type of symptoms & $0.69^{* *}$ \\
Incubation period (days) & $-0.05 \mathrm{tn}$ \\
Numbers of fruit & $-0.16^{*}$ \\
Weight of fruit per plant $\left(\mathrm{g}\right.$ plant $\left.{ }^{-1}\right)$ & $-0.07 \mathrm{tn}$ \\
\hline
\end{tabular}

Effect of additive, dominance and interactions between genes contribute significantly in character inheritance of disease intensity, score/type of symptoms, and the amount of fruit. In the character inheritance, dominance effect is greater than the additive effect of the characters of intensity of disease, scores/type of symptoms, whereas for fruit number the additive effect is greater than dominant influence. The magnitude of the effect will be seen from the dominance $(\mathrm{H} 1 / \mathrm{D})^{1 / 2}$. According to [16], value of $(\mathrm{H} 1 / \mathrm{D})^{1 / 2}$ is greater than one indicates over-dominance, while the value $(\mathrm{H} 1 / \mathrm{D})^{1 / 2}$ between zero and one shows partial dominance.

The interaction between genes showed that the inheritance of the characters needs at least two loci that contribute to enable the interaction between genes in these loci. Results of genetic parameter estimation values of $\mathrm{h} 2 / \mathrm{H} 2$ (describing the number of groups of genes that play a role in the inheritance of the character and cause dominance), shows the character of this interaction is controlled by at least one group of genes while the intensity of the disease character, score/type of symptoms and the number of fruits, number groups of genes do not meet the requirement. This is caused the estimation value of the parameter $\mathrm{h} 2 / \mathrm{H} 2$ will be smaller with the interaction between genes [16].

Dominance and influence of the interaction between genes is a non additive effect. From the standpoint of chili pepper plant breeding, self-pollinated plants (open pollinated plants), the selection is made to the effect of additives in the expectation of collecting a superior genotypes, the selection becomes ineffective if a superior genotype is determined by the influence of dominance and interaction between genes. Because these characters are determined by the strong dominance and interaction between genes, then the selection to the character of chili pepper plant resistance to Begomovirus can be done in the next generation. But the effect of this dominance can be utilized for the manufacture 
of hybrid varieties of chili pepper, especially characters that have a high dominance. For the character and intensity of disease scores/type symptoms, heritability value in a broad sense and narrow sense are high category, so the opportunity of that characters to be inherited to the offspring are high. According to, if a character that has a dominant effect is high, then genetic progress will be achieved through the use of heterosis.

In the breeding programs of chili pepper plant for resistance to Begomovirus, resistant genotypes are usually chosen based on its ability to defend against infection of Begomovirus or low disease intensity and scores/type of symptom. Results of estimation of genetic parameters for the intensity of the disease and scores / type of symptoms are controlled by three genetic component namely additive, dominance and interaction of genes simultaneously. Because of the strong influence of dominance and the interaction between the genes, selection of resistant genotypes using the characters of disease intensity and scores/type symptoms in the chili pepper plant breeding program can be done. Based on broad and narrow sense heritability, both characters can be used as selection criteria because it has high heritability. Results of evaluation showed that F1 plants have a higher intensity of disease than the average parent. This indicated that resistant character controlled by dominant genes. This is in line with the estimation of genetic parameters $\mathrm{r}(\mathrm{Wr}+\mathrm{Vr}$, positive Yr) that hold a dominant character to vulnerability character. This can be seen from the positive direction of the dominance of $\mathrm{r}(\mathrm{Wr}+\mathrm{Vr}$, positive $\mathrm{Yr}$ ). For example offspring from cross IPBC10 (somewhat resistant) with IPBC12 (resistant) is resistant. Offspring from cross IPBC12 (resistant) with 35C (highly susceptible) will produce offspring that are resistant, but its resiprocal cross generate plants moderately susceptible. The inheritance of disease intensity character may be extrachromosomal effect. In breeding programs with the aim of producing hybrid chili pepper plant, the selection of parent as the female parent is a plant that is resistant.

Plant breeding programs for disease resistance generally requires resistant plants with higher yield potential, but in fact many varieties that resistant are low yield potential. In this study, there is a significant and positive correlation between the intensity of the disease and a score/type symptoms $(0.69 * *)$, significant and negative correlation with the number of fruits per plant $(-0.16 *)$, but negatively and not significantly correlated with the amount of fruit ($\left.0.07^{\mathrm{tn}}\right)$. This shows that plants with lower disease intensity and low score/type of symptom will have many number of fruit, number of fruit correlates positively and significant with the weight of fruit per plant $(0.79 * *)$.

Based on the behavior of genes that control the intensity of the disease, controlled the influence of dominance and interaction between genes, in which the resistant plants (lower disease intensity) dominant against the vulnerable, also the weight of fruit per plant were dominant against a low height, then the appropriate breeding method for the formation of resistant varieties Begomovirus with high production is a method of bulk or pedigres. But the effect of dominance contained in these characters is also possible to assemble hybrid varieties.
Population of the cross that has potential to be further investigated in connection with disease resistance and high yield is a cross of IPBC10 and IPBC12 for Begomovirus resistance properties, but have less commercial agronomic characters compare with IPBC15 and IPBC14 that moderatelay vulnerable but have good agronomic characters. Crosses of these resistance genes are expected to collect high yield genes in F1.

\section{CONCLUSIONS}

Incubation period and the weight of fruit per plant variables are controlled by a group of genes that do not interact with each other, while for the intensity of the disease variable, score / type of symptoms and the number of pieces is controlled by a group of genes that interact. Disease resistance characteristics (disease intensity, score / type of symptoms and the incubation period) have a level of dominance that is over-dominant, while the production characteristics (the number and weight of fruit per plant) have a level of partial dominance. There is reciprocal effect on all of the observed characteristics, which indicates their influence on the extrachromosomal inheritance on the observed characteristics. Dominant genes tend to be contained in IPBC10 and IPBC12 genotype for resistance characteristic to Begomovirus character, while for the production characteristics are IPBC18, IPBC15 and IPBC14 genotype. Resistant characteristic (lower disease intensity) is dominant to vulnerable characteristic (high-intensity disease), and many fruit weight is dominant to slight.

\section{ACKNOWLEDGMENT}

We would like to thank Directorate of Research and Community Service, Directorate General of Higher Education, Ministry of Education and Culture through the Graduate Research Grants for Prof. Dr.Ir. Sriani Sujiprihati,

\section{REFERENCES}

[1] Hidayat SH, Rusli E, Aidawati N. 1999. Penggunaan primer universal dalam polymerase chain reaction untuk mendeteksi virus gemini pada cabe. Di dalam: Prosiding Kongres Nasional XV dan Seminar Ilmiah Perhimpunan Fitopatologi Indonesia. Purwokerto, 16-18 September 1999. hlm 355-359.

[2] Ganefianti D.W., S.Sujiprihati S, Hidayat SH, Syukur M. 2008. Metode penularan dan uji ketahanan genotipe cabai (Capsicum spp.) terhadap Begomovirus. Akta Agros.II(2): 162-169.

[3] Johnson LPV. 1963. Applications of the diallel cross technique to plant breeding. P.561-569. Di dalam Hanson WD and Robinson HF (eds.). Statistical Genetics and Plant Breeding.National Acad of.SciNational Res. Council. Washington DC.

[4] Khan AS, Habib I. 2003. Gene action in five parent diallel cross of spring wheat (Triticum aestivum L.) Pakistan J Bio Sc. 6:1945-1948.

[5] Baihaki A. 2000. Teknik Rancang dan Analisis Penelitian Pemuliaan . Bandung. Universitas Padjadjaran

[6] de Sousa JA, Maluf WR. 2003. Diallel analysis and estimation of genetic parameters of hot pepper (Capsicum chinense Jacq). Sci Agricola. 60(1):105-113.

[7] Lapidot M, Friedmann M. 2002. Breeding for resistance to whitefly-transmitted geminivirus. Ass Apl Biol 109-127.

[8] Monci F, Garcia-Andres S, Maldonado JA, Moriones E. 2005. Resistance to monopartite Begomovirus associated with the bean leaf crumple disease in Phaseolus vulgaris controlled by a single dominant gene. The Am Phyt Soc. 95(7):819-826.

[9] Djatmiko HA, Kharisun, Prihatiningsih N. 2000. Potensi Trichoderma harzianum, Pseudomonas fluorescens dan zeolit terhadap penekanan layu sklerotium, peningkatan pertumbuhan dan produksi kedelai. J Penl Pert Agrin. 4:14-24. 
[10] Arif, A. B., S. Sujiprihati, dan M. Syukur. 2012. Pendugaan pameter genetik pada beberapa karakter kuantitatif pada bersilangan antara cabai besar dengan cabai keriting (Capsicum annuum L.). Jurnal Agronomi Indonesia 40(2): 119-124.

[11] Jumbo, M.B, Carena MJ. 2008. Combining ability, maternal and reciprocal effects of elitemaize population hybrid. Euphytica 162: 325-333.

[12] Anandhi, K., K.M.A. Khader. 2011. Gene effect of fruit yield and leaf curl vuris resistance in inspecific crosses on chili (Capsicum annuum L. And C. frutescens L.). J. Trop. Agric. 49: 107-109.
[13] Istiqlal, M.R.A., M. Syukur, dan Y. Wahyu. 2014. Analisis diale untuk pendugaan parameter genetik komponen hasil pada cabai (Capsicum annuum L.) menggunakan Metode Hayman. J. Agron.indonesia 42(2): 124-129.

[14] Falconer DS. 1961. Introduction to Quantitative Genetics. Edinburgh: Oliver 7 Boyd.

[15] Marame, F., L. Desalegne, S. Harjit, C. Fininsa, R. Sgvald. 2008 Genetics components and heretability of yield and yield related trats in hot pepper. Res. J. Agric. Biol. Sci. 4: 803-809.

[16] Hayman BI. 1954. The theory and analysis of diallel crosses.Genetics 39:789-809. 